\title{
PURIFICATION OF AERATED GROUND-WATER USING RAPID SAND FILTERS
}

\author{
Eman Maher Ahmed*, N.A. Ali, A.A. Ali and M.S. Dardir ${ }^{* *}$ \\ Civil Engineering Department, Faculty of Engineering, Assiut University, \\ Assiut, Egypt.
}

(Received October 7, 2009 Accepted October 20, 2009).

\begin{abstract}
Most of arid and rural areas in Egypt depend on groundwater as a main source of drinking water. The main problem in this source of water is the appearance of iron salts which affects the water potability. Several studies had been applied to solve the iron problem in water. Aeration is considered the best and cheapest way to remove iron salts from groundwater. Aeration depends on oxidation of soluble iron (II) to the insoluble iron (III) form which it can be removed by using filtration following sedimentation or filtration only depending on iron concentration on the raw water.

This study is conducted to investigate the success of a proposed technique using aeration followed by filtration without chemical additions for iron removal. The effect of different filtration of sand depths, filtration rates and raw iron concentrations on the efficiency of removal of iron and turbidity are considered.

The research is applied on tap water with different values of iron concentrations. The predetermined values of iron concentrations were $1.5,2$, and $3.33 \mathrm{mg} / \mathrm{l}$ which chosen to give different values of turbidity after aeration (13,20, and $30 \mathrm{NTU}$ respectively) and to cover the range of the average values (about 1 to $5 \mathrm{mg} / \mathrm{l}$ ) which appear in the most of water wells in Upper Egypt. Results indicated that, for all values of iron concentrations and effluent turbidity less than $1 \mathrm{NTU}$, the economical sand depth is $40 \mathrm{~cm}$ when the influent turbidity $<13 \mathrm{NTU}$, filtration rate $<$ $200 \mathrm{~m}^{3} / \mathrm{m}^{2} /$ day and when influent turbidity $<20 \mathrm{NTU}$, filtration rate $<$ $120 \mathrm{~m}^{3} / \mathrm{m}^{2} /$ day. Also, the best sand depth is $60 \mathrm{~cm}$ when the influent turbidity $<30 \mathrm{NTU}$ with filtration rate $<80 \mathrm{~m}^{3} / \mathrm{m}^{2} /$ day. Also, the best sand depth is $>70 \mathrm{~cm}$ when the influent turbidity $<30 \mathrm{NTU}$ and filtration rate in the rang from 80 to $200 \mathrm{~m}^{3} / \mathrm{m}^{2} /$ day.
\end{abstract}

\section{1- INTODUCTION}

Iron is not harmful, but undesirable on aesthetic grounds, making the water unpalatable. When water, containing a lot of iron, is used for laundry, it causes brown stains which are difficult to remove. In recognition of these problems, the World Health Organization (WHO) established recommended maximum concentrations for iron in public water equal $(0.3 \mathrm{mg} / \mathrm{l})$. However, in setting these limits, consideration was also given to the limitations of analytical testing procedures and to the feasibility of providing the required degree of treatment. 
The limit of the Egyptian code and slandered is $0.3 \mathrm{mg} / \mathrm{l}$ for filtrated surface water and $1.0 \mathrm{mg} / \mathrm{l}$ for a mix of groundwater and surface water. Several studies about iron and manganese removal from drinking water were conducted and conclusions were drawn $[1,6,9$, and 10$]$.

Aeration serves a number of useful purposes in water treatment. Many of the problem substances that aeration removes are most generally found in ground waters. These substances must be present at levels that pose a threat to health or cause excessive consumption of chemicals in the water treatment process before a separate unit operation of aeration is incorporated into the treatment train [5]

Aeration of iron bearing water has three purposes:

a- To transfer oxygen to the water for oxidation of iron and manganese.

b- To remove any volatile organics that may be present and that reduce the efficiency of subsequent processes due to their oxidant demand [8]j

c- To remove carbon dioxide and hydrogen sulphide gases.

The reaction of soluble iron with oxygen during aeration process is shown in Eq. (1).

$4 \mathrm{Fe}\left(\mathrm{HCO}_{3}\right)_{2}+10 \mathrm{H}_{2} \mathrm{O}+\mathrm{O}_{2} \stackrel{\text { aeration }}{\longrightarrow} 4 \mathrm{Fe}(\mathrm{OH})_{3} \downarrow+8 \mathrm{H}_{2} \mathrm{CO}_{3}$

The removal of iron is actually a two-step reaction. First, the soluble ferrous bicarbonate $\left[\mathrm{Fe}\left(\mathrm{HCO}_{3}\right)_{2}\right]$ is converted to the less soluble form, ferrous hydroxide [Fe $\left.(\mathrm{OH})_{2}\right]$.

Then, under further aeration, the ferrous hydroxide is converted to the insoluble form, ferric hydroxide $\left[\mathrm{Fe}(\mathrm{OH})_{3}\right]$, which will filter out or settle out of solution as a fluffy rust-colored sludge. The reaction works best in the $\mathrm{pH}$ range 7.58.0. It takes about $15 \mathrm{~min}$ to complete in normal conditions. The removal of $1 \mathrm{mg} / \mathrm{L}$ of iron $\left(\mathrm{Fe}^{+2}\right)$ requires about $0.14 \mathrm{mg} / \mathrm{L}$ of oxygen [2].

Aeration techniques include spray, cascade, diffused-air, multiple-tray, and packed-column systems [ $3 \& 4$ ]. The object of all designs of aeration techniques is maximizing the area of contact between the water and air and to produce motion of one fluid relative to the other so that exchange can be enhanced by maximizing the concentration gradient [7].

Therefore, the objective of this research is to demonstrate the effect of some physical parameters (sand depth, filtration rate and influent concentration iron), on the effluent groundwater quality from down flow direct filtration after using simple aeration.

\section{2- MATERIALS AND METHODS}

The experimental studies were carried out in a pilot-scale water treatment plant contains a group of circular filter columns as shown in Fig. (1). This plant was used to evaluate the removal of iron by aeration and filtration.

The turbid water used in the experimental studies was a mixture of known weight of Ferrous Ammonium Sulfate $\left[\mathrm{Fe}\left(\mathrm{NH}_{4}\right)_{2} \mathrm{SO}_{4} .2 \mathrm{H}_{2} \mathrm{O}\right]$ with tap water to obtain the influent constant concentration iron at the filter inlet [1]. The aeration of raw water was done in a steel tank containing two vanes rotating at a constant speed of $60.0 \mathrm{rpm}$, which is connected to an electric motor of $10.0 \mathrm{HP}$ by a steel shaft. The aeration of this water has been done in the mixing tank with time of mixing about 30 minutes (aeration 
time is constant for all runs) before the beginning of the experimental runs [8]. Two centrifugal pumps were used to pump turbid water from the raw water tank to a constant head tank. By using a control valve, the raw water was regulated and allows flowing down by gravity from the constant head tank to free level Perspex cylinder to have a constant filtration rate. The filter units were constructed of $10 \mathrm{~cm}$ ID Perspex column giving a surface area of $0.008 \mathrm{~m}^{2}$ with a maximum sand bed depth of $0.7 \mathrm{~m}$. The effective size and the uniformity coefficient of the sand are $0.682 \mathrm{~mm}$ and 1.6 respectively. Gravel layer of $30 \mathrm{~cm}$ was put under the sand layer as supporting layer. The filter was operated at flow rate that gives filtration rates of 60, 80, 100, 120 and $200 \mathrm{~m}^{3} / \mathrm{m}^{2} /$ day. The iron concentration of raw water was changed in the raw water tank three times $(1.5,2$ and $3.33 \mathrm{mg} / \mathrm{l})$.

Samples of filtered water were collected simultaneously at the outlet of the filter, and at different locations of the filter length (at 40, 50, 60, and $70 \mathrm{~cm}$ ) from the entrance of the filter. The effluent leaves the system of filtration to a drainage channel. The influent and effluent turbidity are measured using turbidemter model orbeco-hellige. Concentrations of total iron were measured by the spectrophotometer $\mathrm{dr} / 2000$.

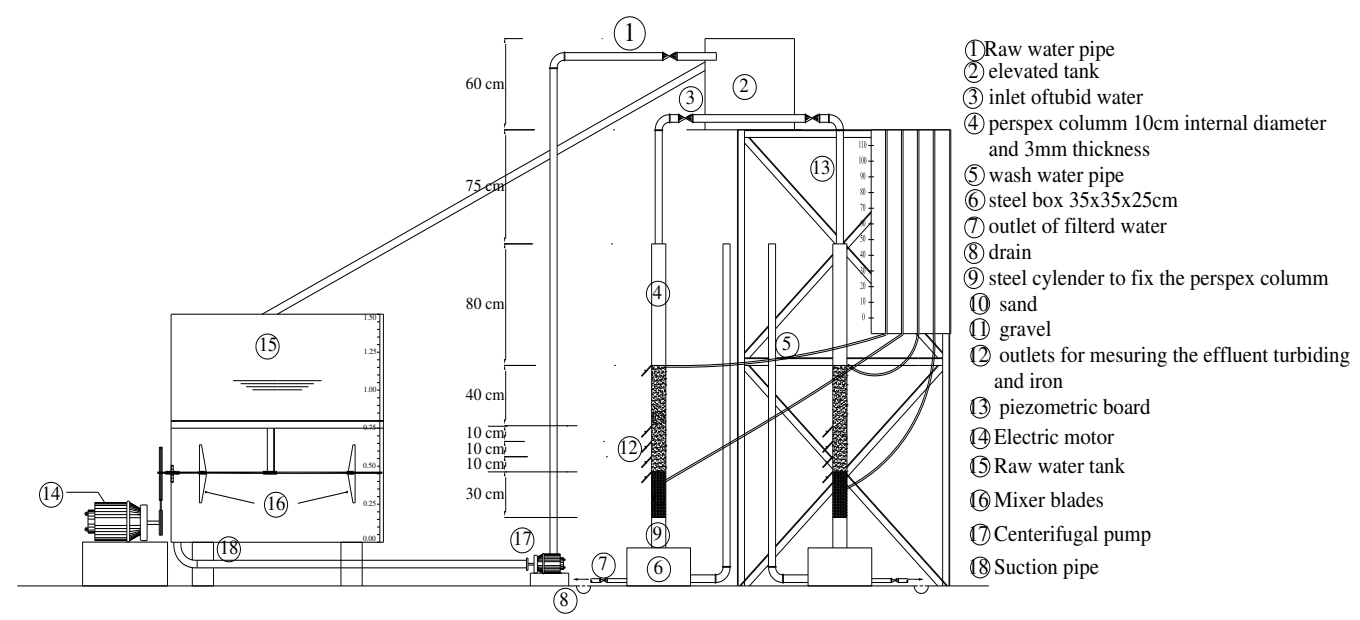

Fig. (1) Schematic diagram of the pilot filtration plant

\section{2-1 Experimental Limitations}

For all experimental runs, the run duration lasts for about 24 hours until the backwash is needed. The increase of the head loss can be estimated as $7 \mathrm{~cm}$ at the beginning of the run and reached about $45 \mathrm{~cm}$ at the end of the run. The $\mathrm{pH}$ values are measured through all runs and their values ranging between 7.5 and 7.58. The values of influent turbidity, iron concentration of raw water, sand depths, and filtration rates are varied as shown in Fig. (2). 


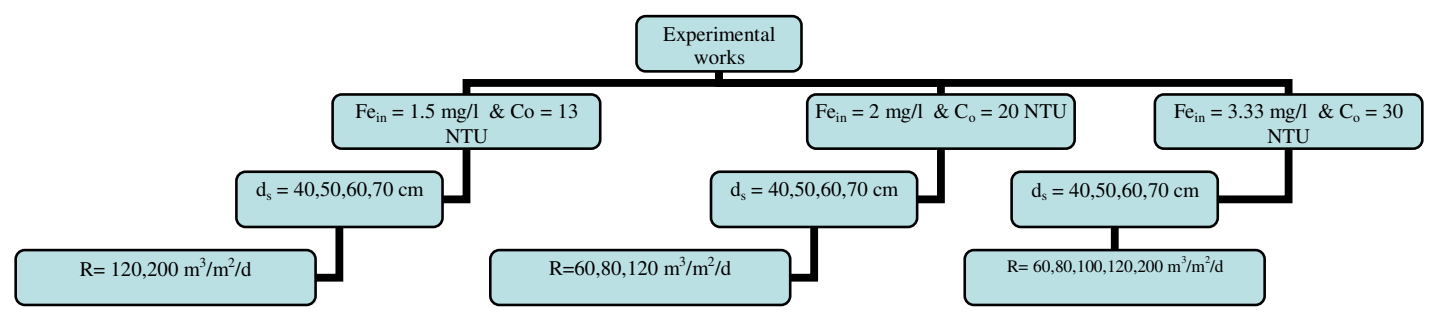

Fig. (2) Schematic diagram of experimental parameters

\section{3- RESULTS AND DISCUSSIONS}

The main results are summarized as follows:

\section{3-1 Effect of Sand Depth on the Effluent Turbidity and Iron Concentration}

\section{3-1-1 For influent turbidity $\mathrm{C}_{0}=13 \mathrm{NTU}$ (iron concentration $\mathrm{Fe}_{\text {in }}=1.5 \mathrm{mg} / \mathrm{l}$ )}

Figure (3a) shows that the effluent turbidity $(\mathrm{Ce})$ decreases with time (t) for different sand depths and the values of effluent turbidity are less than 1 NTU. When the filtration rate increases; $R=200 \mathrm{~m}^{3} / \mathrm{m}^{2} /$ day, as shown in Fig. (4a), the effluent turbidity decreases with time, and after certain time, it starts to increase again becouse of rapid clogging of filter bores due to high rate and small sand depth. For small sand depth $(40$ and $50 \mathrm{~cm}$ ) the effluent turbidity starts to increase after almost 9 hours, while it starts to increase after about 16 hours for greater sand depth $(60$ and $70 \mathrm{~cm})$. For all sand depths $>40 \mathrm{~cm}$, the values of effluent turbidity was less than 1 NTU for R $=120 \mathrm{~m}^{3} / \mathrm{m}^{2} /$ day and varies between 0.02 to 1 NTU. Figures (3b) and (4b) illustrate the relationships between the effluent iron concentration (Ie) and elapsed time (t) for different values of sand depth (ds) at filtration rates ( $R=120$ and $200 \mathrm{~m}^{3} / \mathrm{m}^{2} /$ day). From these Figures it is clearly noticed that the effluent total iron concentration (Ie) is slightly decreasing with the time ( $\mathrm{t}$ ) during the first few hours of the run, after that, it starts to increase.

For $\mathrm{R}=120 \mathrm{~m}^{3} / \mathrm{m}^{2} / \mathrm{d}$

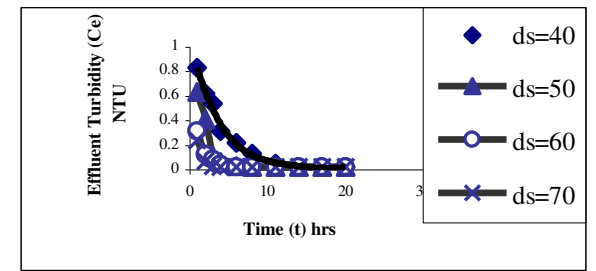

Fig. (3a) The effluent turbidity versus time at different sand depths

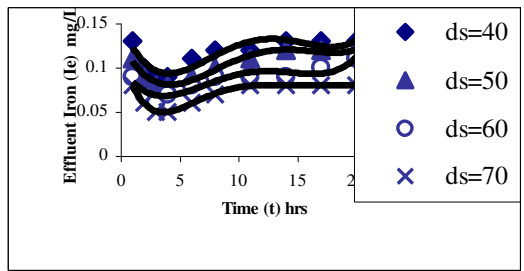

Fig. (3b) The effluent iron conc. versus time at different sand depths 
For $\mathrm{R}=200 \mathrm{~m}^{3} / \mathrm{m}^{2} / \mathrm{d}$

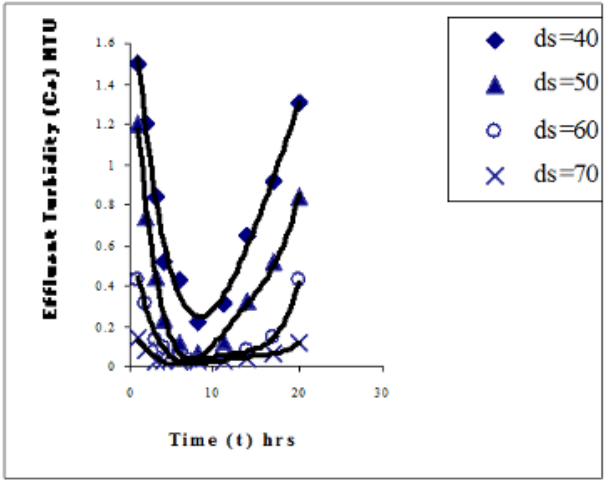

Fig. (4a) The effluent turbidity versus time at different sand depths

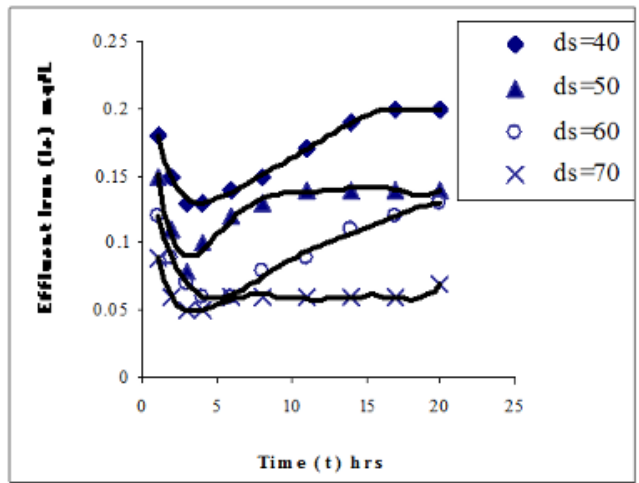

Fig. (4b) The effluent iron conc. versus time at different sand depths

\section{3-1-2 For influent turbidity $\mathrm{C}_{0}=20 \mathrm{NTU}$ (iron concentration $\mathrm{Fe}_{\text {in }}=2 \mathrm{mg} / \mathrm{l}$ )}

The same phenomenal happens at small values of filtration rate (for example $\mathrm{R}=60$ $\mathrm{m}^{3} / \mathrm{m}^{2} /$ day) as shown in Figs. (5a) and (6a). For filtration rate $\mathrm{R}=120 \mathrm{~m}^{3} / \mathrm{m}^{2} /$ day, the effluent turbidity reaches to a value less than 1 NTU after 4 and 2 hours at sand depths 40 and $50 \mathrm{~cm}$ respectively as shown in Fig. (7a). From Figs. (5b) and (6b) the effluent iron concentration (Ie) is increasing with time during the filtration run length for filtration rates $\mathrm{R}=60$ and $80 \mathrm{~m}^{3} / \mathrm{m}^{2} /$ day. It is beginning with value equal to 0.25 $0.30 \mathrm{mg} / \mathrm{l}$ and ending with value $0.6-0.75 \mathrm{mg} / \mathrm{l}$. For filtration rate $\mathrm{R}=120 \mathrm{~m}^{3} / \mathrm{m}^{2} /$ day, the values of the effluent iron concentration (Ie) is decreasing with short time ( one hour) and after that it begins to increasing with time until the run end as shown in Figs. (7b).

For $\mathrm{R}=60 \mathrm{~m}^{3} / \mathrm{m}^{2} / \mathrm{d}$

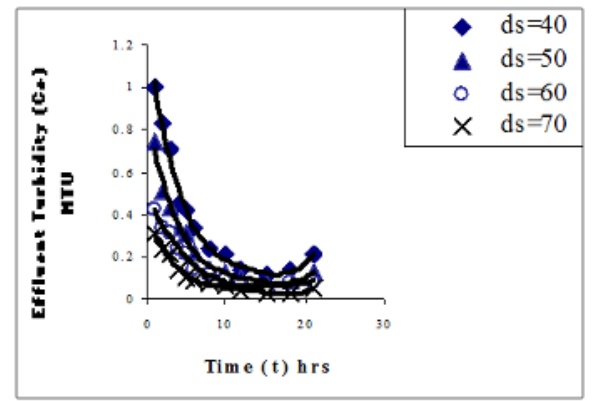

Fig. (5a) The effluent turbidity versus time at different sand depth

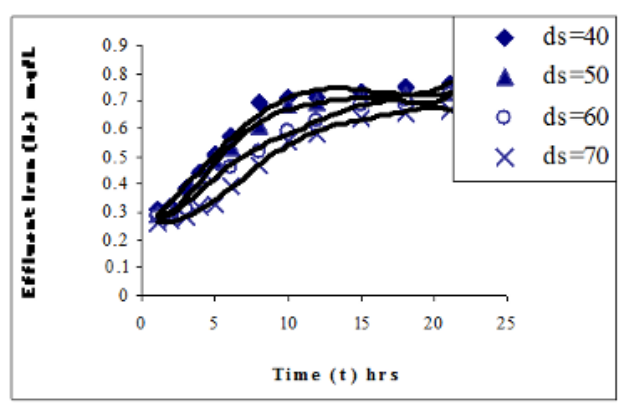

Fig. (5b) The effluent iron conc. versus time at different sand depths 
For $\mathrm{R}=80 \mathrm{~m}^{3} / \mathrm{m}^{2} / \mathrm{d}$

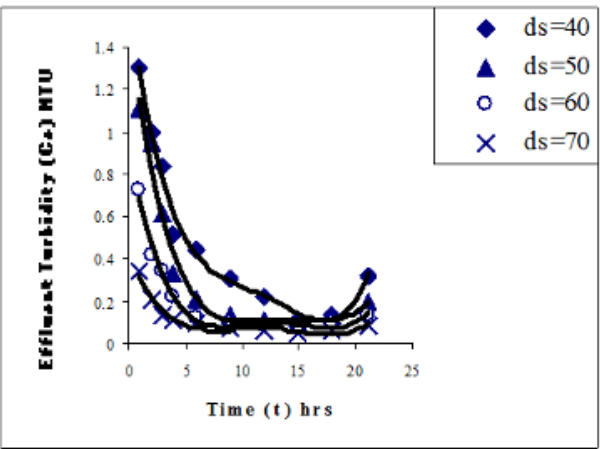

Fig. (6a) The effluent turbidity versus time at different sand depths

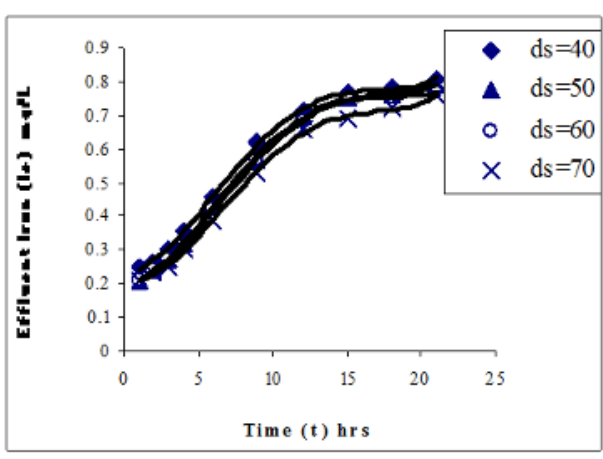

Fig. (6b) The effluent iron conc. versus time at different sand depths

For $\mathrm{R}=120 \mathrm{~m}^{3} / \mathrm{m}^{2} / \mathrm{d}$

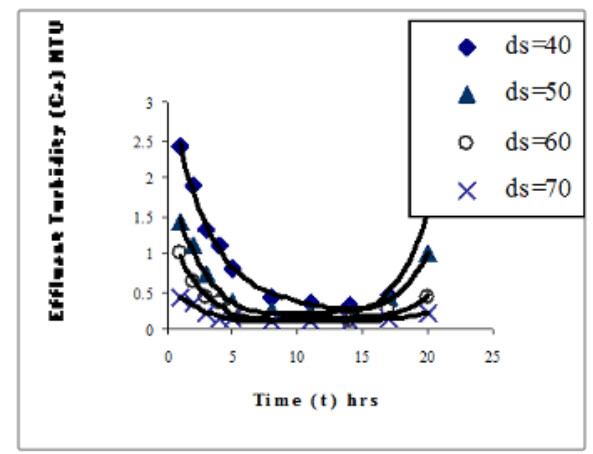

Fig. (7a) The effluent turbidity versus time at different sand depths

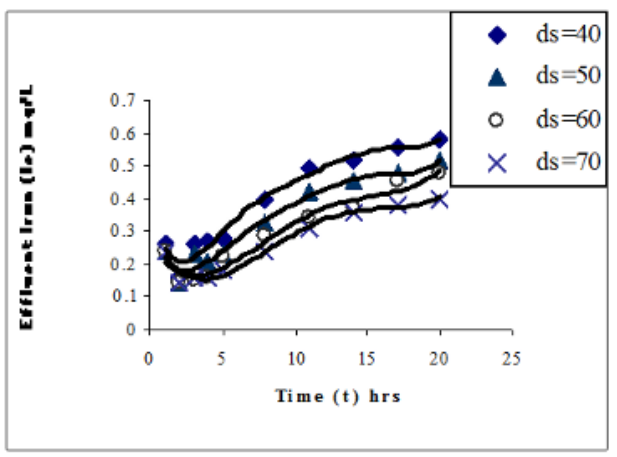

Fig. (7b) The effluent iron conc. versus time at different sand depths

From the above figures, effluent turbidity decreases with time in all runs during 20 hours. Concentration of total iron increases with time from $0.2 \mathrm{mg} / \mathrm{l}$ to about $0.8 \mathrm{mg} / \mathrm{l}$ in all runs.

\section{3-1-3 For influent turbidity $C_{0}=30$ NTU (iron concentration $F_{i n}=3.33 \mathrm{mg} / \mathrm{l}$ )}

For high limit of influent turbidity $\left(\mathrm{C}_{0}=30 \mathrm{NTU}\right)$ and high limit of filtration rate $(\mathrm{R}=$ $200 \mathrm{~m}^{3} / \mathrm{m}^{2} /$ day), the results are shown in Fig (12a). The effluent turbidity is increased up to a value equal to (5 NTU) after about 2 hours at depth of sand equal to $40 \mathrm{~cm}$, after about 4 hours at depth of sand $\mathrm{d}_{\mathrm{s}}=50 \mathrm{~cm}$, and after about 7 hours at sand depth $=60 \mathrm{~cm}$. It is noticed the high value of effluent turbidity in sand depth $d_{\mathrm{s}}=70$ $\mathrm{cm}$ is less than $5 \mathrm{NTU}$ through the experimental run. In the low values of filtration rate $\left(\mathrm{R}=60-120 \mathrm{~m}^{3} / \mathrm{m}^{2} /\right.$ day $)$, the effluent turbidity decreases with time. After about 4 hours at sand depths ds $=40$ and $50 \mathrm{~cm}$ and after about 6 hours at ds $=60$ and $70 \mathrm{~cm}$, the effluent turbidity starts to increase but less than 5 NTU except at the end of run for $d_{s}=40 \mathrm{~cm}$ see Figs. (8a) and (9a). At filtration rate $R=100 \mathrm{~m}^{3} / \mathrm{m}^{2} /$ day the effluent turbidity decrease with time for short period ( about 3 hours ) at sand depths $d_{s}$ $=40$ and $50 \mathrm{~cm}$ and after that it increases with time as shown in Fig. (10a). 
It is noticed from Fig. ( $8 \mathrm{~b})$ that at low filtration rate $\left(\mathrm{R}=60 \mathrm{~m}^{3} / \mathrm{m}^{2} /\right.$ day), the effluent iron concentrations $\left(I_{e}\right)$ seeme to be constant during the first hours (about 3 hours) and increase after that time. For filtration rate $\left(\mathrm{R}=80 \mathrm{~m}^{3} / \mathrm{m}^{2} /\right.$ day), the effluent iron concentration is increasing with time and noticed that a high increasing is noticed at a value of sand depth, ds $=40 \mathrm{~cm}$ (Fig. (9b)). When filtration rate increases ( $\mathrm{R}=$ $100 \mathrm{~m}^{3} / \mathrm{m}^{2} /$ day), the values of the effluent iron concentration are decreasing with the time during about 4 hours and starting to increasing after that time as shown in Fig. (10b). At value of filtration rate equal to $120 \mathrm{~m}^{3} / \mathrm{m}^{2} /$ day, the effluent iron concentrations are increasing with time from the beginning of the run as shown in Fig.(11b). Finally, for high filtration rate $R=200 \mathrm{~m}^{3} / \mathrm{m}^{2} /$ day, the rate of increasing of the effluent iron concentration is high so the run was stopped after time $(\mathrm{t}=11$ hours $)$ as illustrated in Fig. (12b).

For $\mathrm{R}=60 \mathrm{~m}^{3} / \mathrm{m}^{2} / \mathrm{d}$

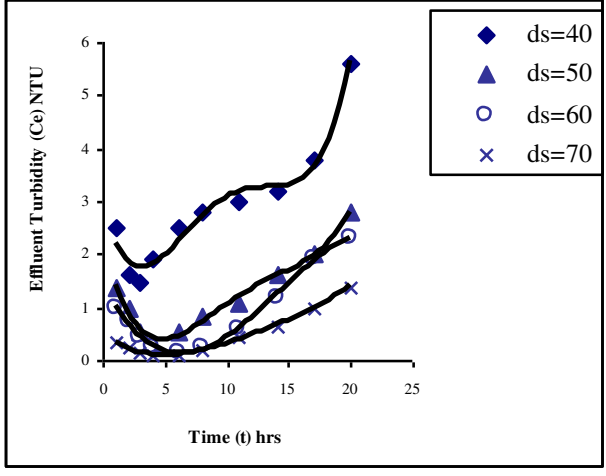

Fig. (8a) The effluent turbidity versus time at different sand depths

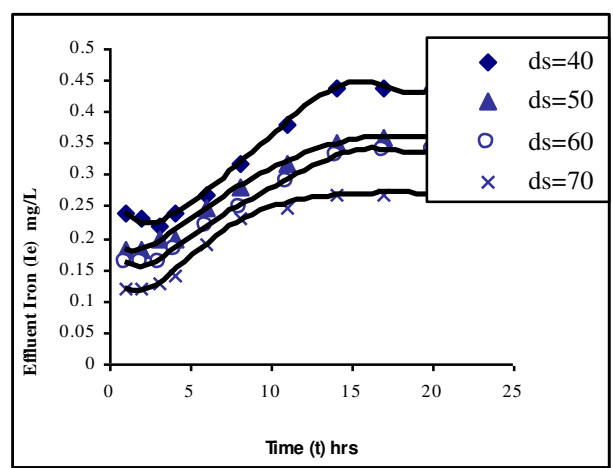

Fig. (8b) The effluent iron conc. versus time at different sand depths

For $\mathrm{R}=80 \mathrm{~m}^{3} / \mathrm{m}^{2} / \mathrm{d}$

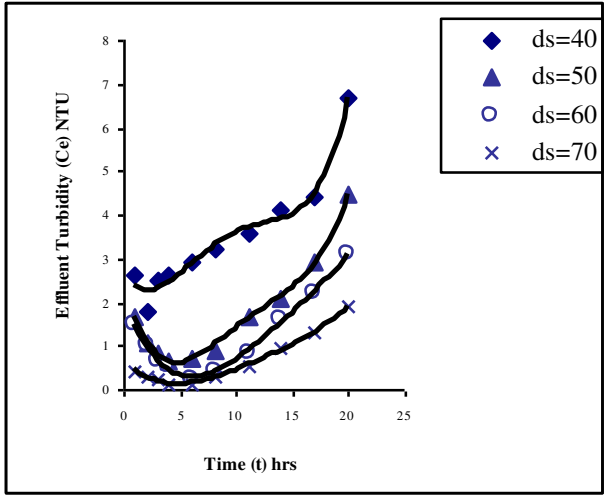

Fig. (9a) The effluent turbidity versus time at different sand depths

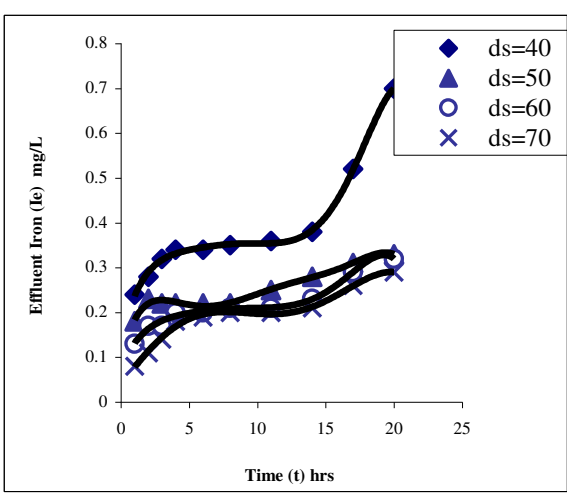

Fig. (9b) The effluent iron conc. versus time at different sand depths 
For $\mathrm{R}=100 \mathrm{~m}^{3} / \mathrm{m}^{2} / \mathrm{d}$

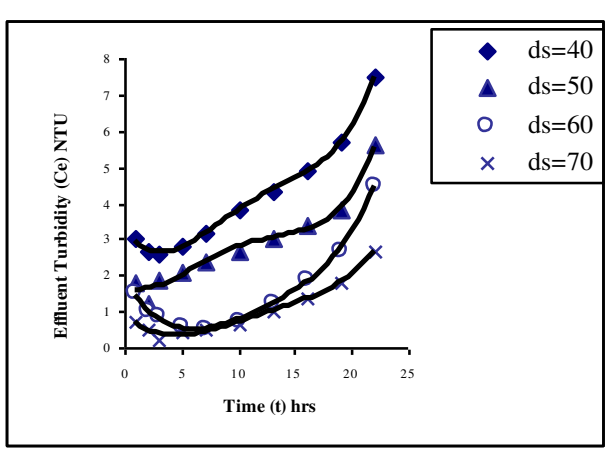

Fig. (10a) The effluent turbidity versus time at different sand depths

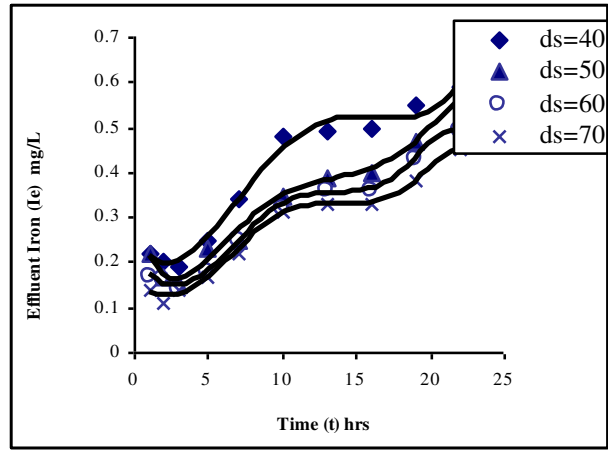

Fig. (10b) The effluent iron conc. versus time at different sand depths

For $\mathrm{R}=120 \mathrm{~m}^{3} / \mathrm{m}^{2} / \mathrm{d}$

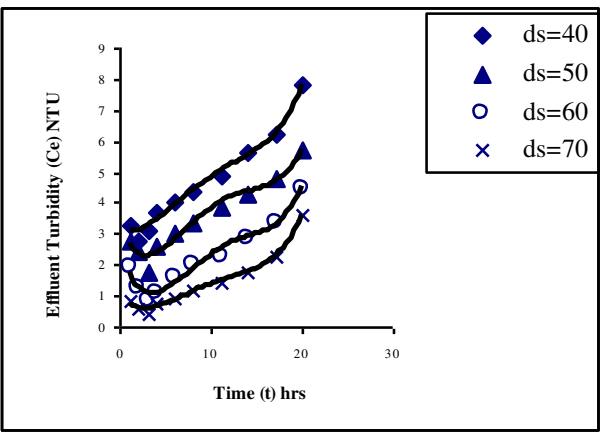

Fig. (11a) The effluent turbidity versus time at different sand depths

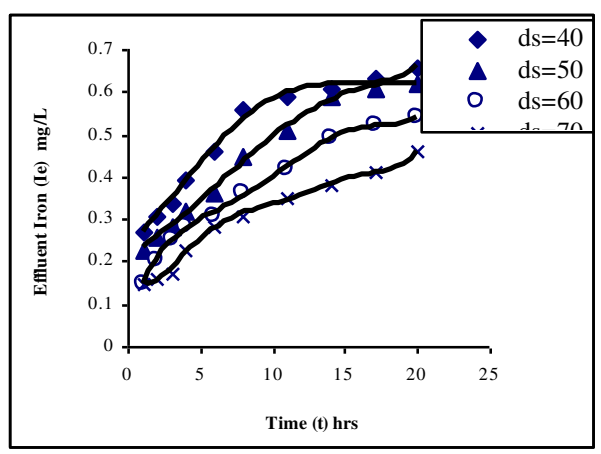

Fig. (11b) The effluent iron conc. versus time at different sand depths

For $\mathrm{R}=200 \mathrm{~m}^{3} / \mathrm{m}^{2} / \mathrm{d}$

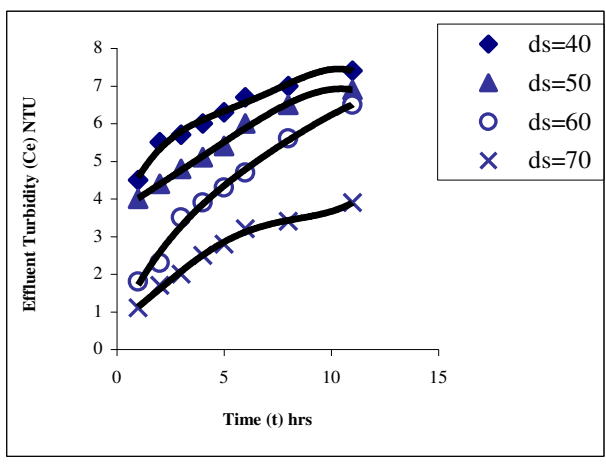

Fig. (12a) The effluent turbidity versus time at different sand depths

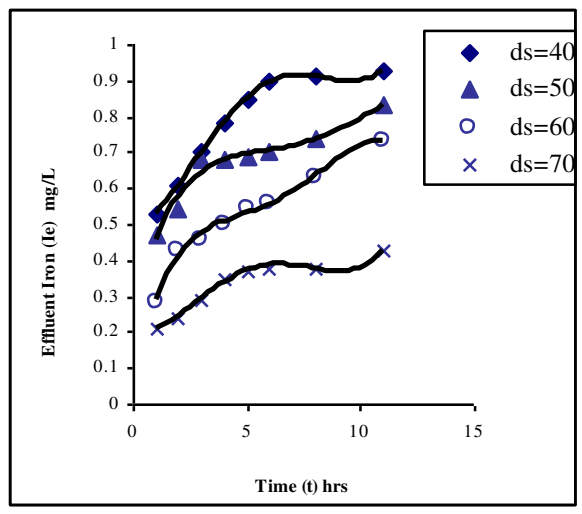

Fig. (12b) The effluent iron conc. versus time at different sand depths 


\section{3-2 Effect of Filtration Rate on The Effluent Turbidity and Iron Concentration}

\section{3-2-1 For influent turbidity $\mathrm{C}_{\mathrm{o}}=13 \mathrm{NTU}$ (iron concentration $\mathrm{Fe}_{\mathrm{in}}=1.5 \mathrm{mg} / \mathrm{l}$ )}

From Figs. (13a) to (16a), it can be noticed that the effluent turbidity decreases with the time for all runs at small filtration rates ( $\mathrm{R}=120 \mathrm{~m}^{3} / \mathrm{m}^{2} /$ day).

But for $R=200 \mathrm{~m}^{3} / \mathrm{m}^{2} /$ day, the effluent turbidity starts to decrease with time in first hours and after that it begins to increase with time for all sand depths.

In small depth ( $\mathrm{ds}=40 \mathrm{~cm}$ ), it is noticed that the effluent iron concentration (Ie) is decreasing slightly with time during the first hours of the run and then starting to increase slowly until the run end as shown in Fig. (13b).

When the sand depth is increased ( $\mathrm{ds}=50,60$ and $70 \mathrm{~cm}$ ), the effluent iron concentration is decreasing rapidly in short time ( 4 hours ) and after that it increases as depicted in Figs. (14b) to (16b).

For $\mathrm{d}_{\mathrm{s}}=40 \mathrm{~cm}$

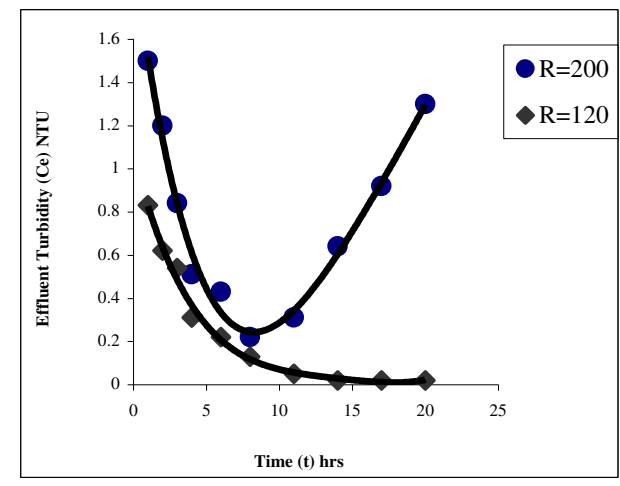

Fig. (13a) The effluent turbidity versus time at different filtration rates

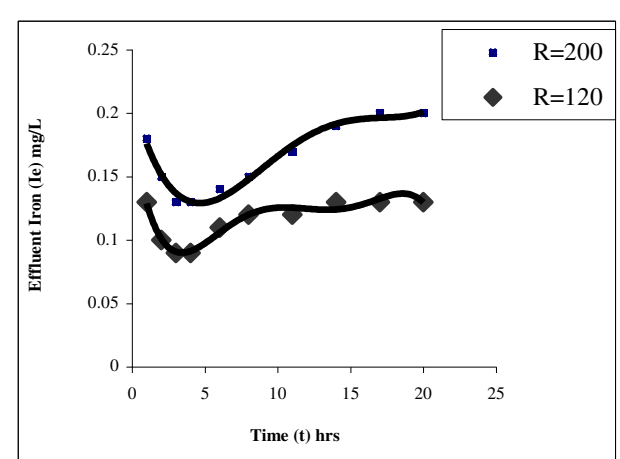

Fig. (13b) The effluent iron conc. versus time at different sand depths

For $\mathrm{d}_{\mathrm{s}}=50 \mathrm{~cm}$

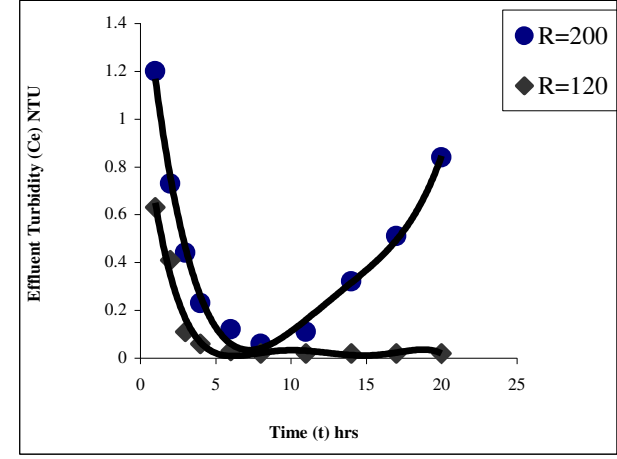

Fig. (14a) The effluent turbidity versus time at different filtration rates

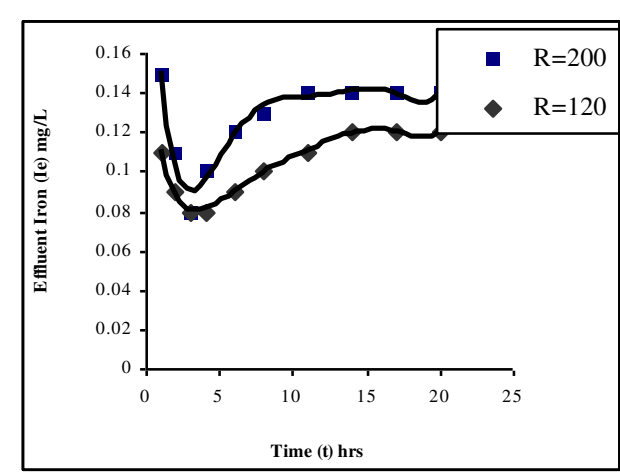

Fig. (14b) The effluent iron conc. versus time at different sand depths 


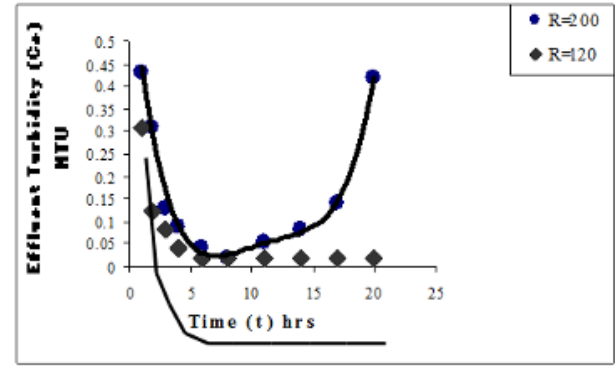

Fig. (15a) The effluent turbidity versus time at different filtration rates

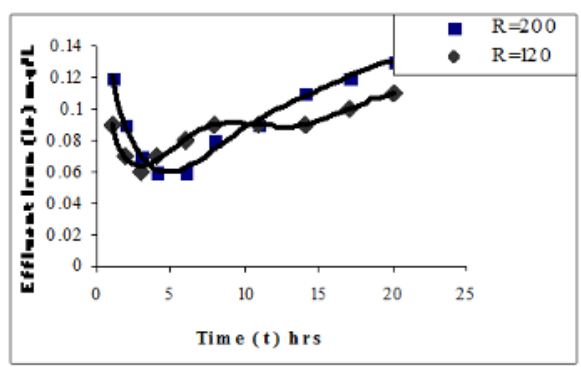

Fig. (15b) The effluent iron conc. versus time at different sand depths

For $\mathrm{d}_{\mathrm{s}}=70 \mathrm{~cm}$

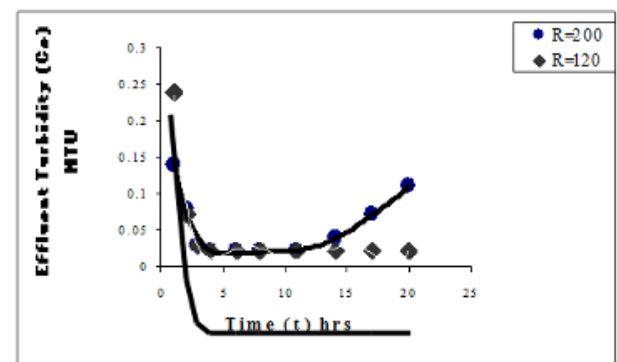

Fig. (16a) The effluent turbidity versus time at different filtration rates

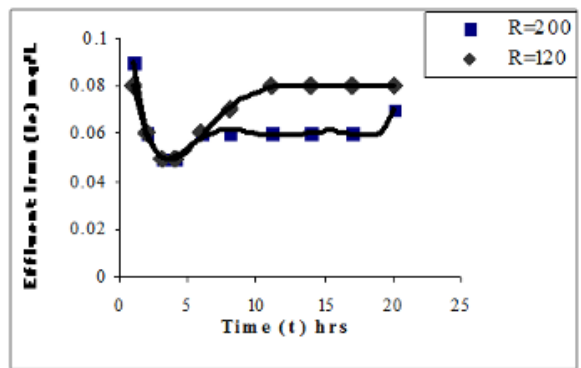

Fig. (16b) The effluent iron conc. versus time at different sand depths

\section{3-2-2 For influent turbidity $\mathrm{C}_{\mathrm{o}}=20 \mathrm{NTU}$ (iron concentration $\mathrm{Fe}_{\mathrm{in}}=2 \mathrm{mg} / \mathrm{l}$ )}

The same phenomena is happened at small filtration rate $\left(R=60\right.$ and $80 \mathrm{~m}^{3} / \mathrm{m}^{2} /$ day). The effluent turbidity is decreasing with time for all runs and starting to increase at the end of the runs. For $\mathrm{R}=120 \mathrm{~m}^{3} / \mathrm{m}^{2} /$ day, the effluent turbidity decreases at the beginning of the run then starting to increase with time as shown in Figs (17a) and (18a).

\section{For $\mathrm{d}_{\mathrm{s}}=60 \mathrm{~cm}$}

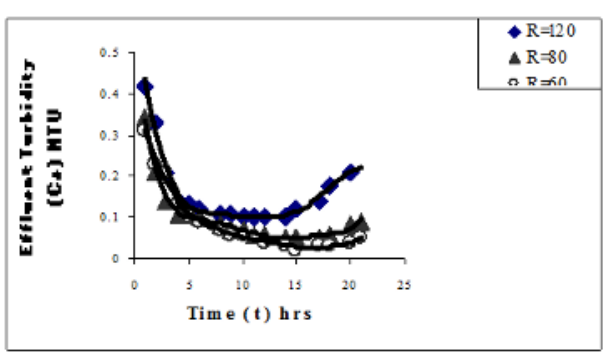

Fig. (17a) The effluent turbidity versus time at different filtration rates

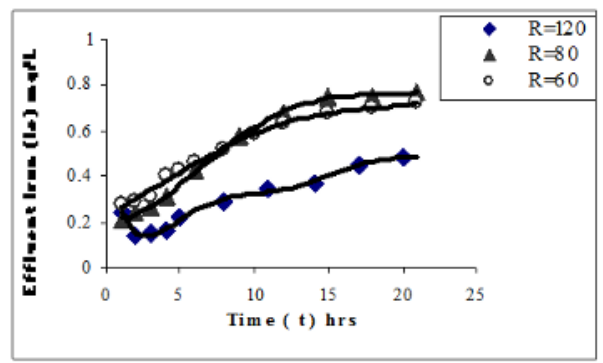

Fig. (17b) The effluent iron conc. versus time at different sand depths 
For $\mathrm{d}_{\mathrm{s}}=70 \mathrm{~cm}$

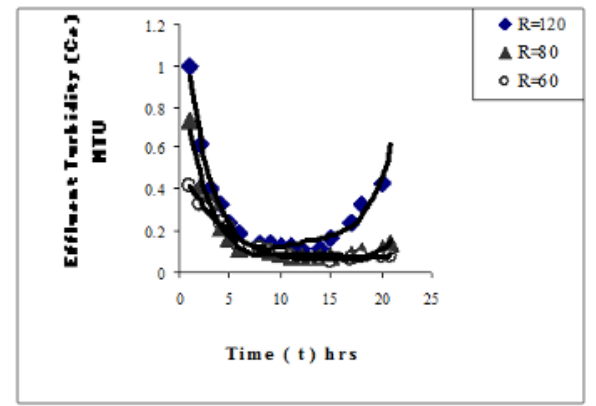

Fig. (18a) The effluent turbidity versus time at different filtration rates

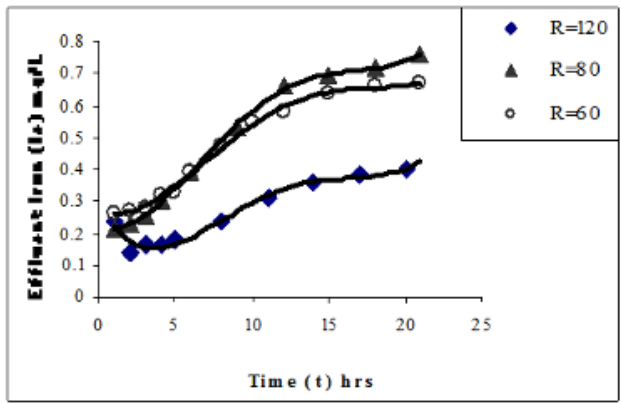

Fig. (18b) The effluent iron conc. versus time at different sand depths

\section{3-2-3 For influent turbidity $\mathrm{Co}=30 \mathrm{NTU}$ (iron concentration Fein $=3.33 \mathrm{mg} / \mathrm{l}$ )}

At sand depth $(\mathrm{ds}=40$ and $50 \mathrm{~cm})$, and filtration rate $60<\mathrm{R}<120\left(\mathrm{~m}^{3} / \mathrm{m}^{2} /\right.$ day $)$, the effluent turbidity decreases for the first 4 hours of the run, and then slightly increases with time. Same are noticed when $\mathrm{ds}=60$ and $70 \mathrm{~cm}$, but after the long time from the beginning of the run. For $\mathrm{R}=200 \mathrm{~m}^{3} / \mathrm{m}^{2} /$ day and for different sand depths, the effluent turbidity increases from the beginning of the run as shown in Fig. (19a).

\section{For $\mathrm{d}_{\mathrm{s}}=70 \mathrm{~cm}$}

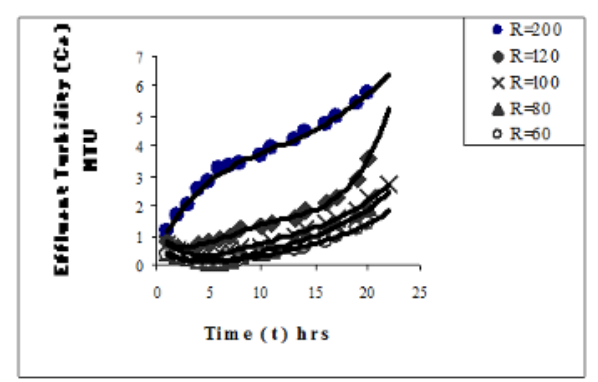

Fig. (19a) The effluent turbidity versus time at different filtration rates

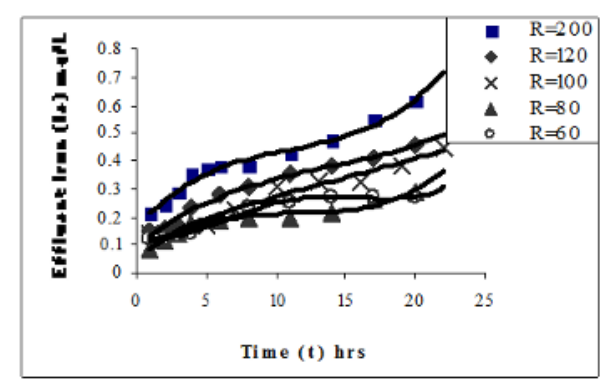

Fig. (19b) The effluent iron conc. versus time at different sand depths

\section{3-3 Effect Of Influent Turbidity \& Iron Concentration on the Effluent Turbidity and Effluent Iron Concentration}

Shown in Figs. (20 to 23) are the plot of effluent turbidity and effluent iron cocn. with the time for different initial concentrations and turbidities at different sand depth with different filtration rates. A low concentration and turbidity is seen at the beginning of filtration processes then they started to increase with the time. Also, with high initial concentration higher turbidities are observed. 
For $\mathrm{d}_{\mathrm{s}}=40 \mathrm{~cm}, \mathrm{R}=120 \mathrm{~m}^{3} / \mathrm{m}^{2} /$ day

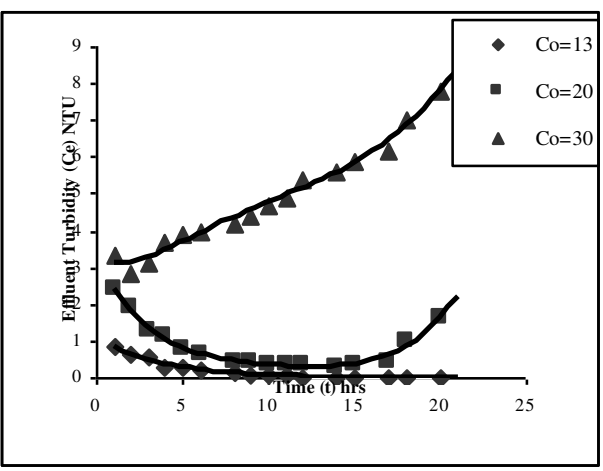

Fig. (20a) The effluent turbidity versus time at different influent turbidity.

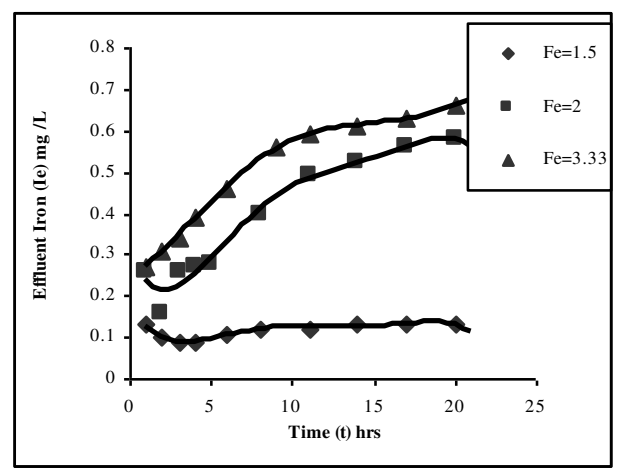

Fig. (20b) The effluent iron versus time at different sand depths

For $\mathrm{d}_{\mathrm{s}}=40 \mathrm{~cm}, \mathrm{R}=200 \mathrm{~m}^{3} / \mathrm{m}^{2} /$ day

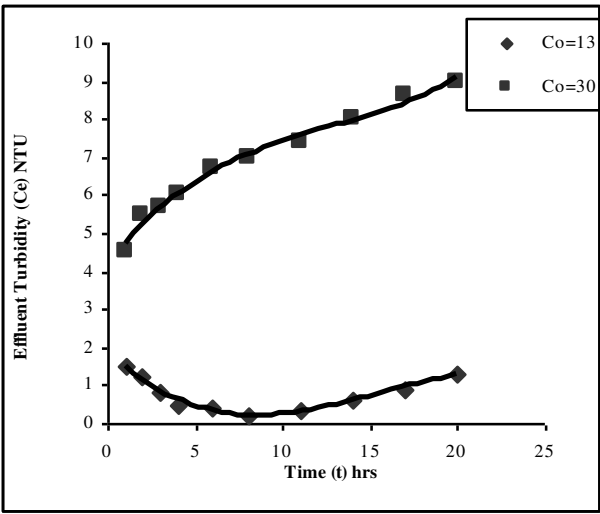

Fig. (21a) The effluent turbidity versus time at different influent turbidity.

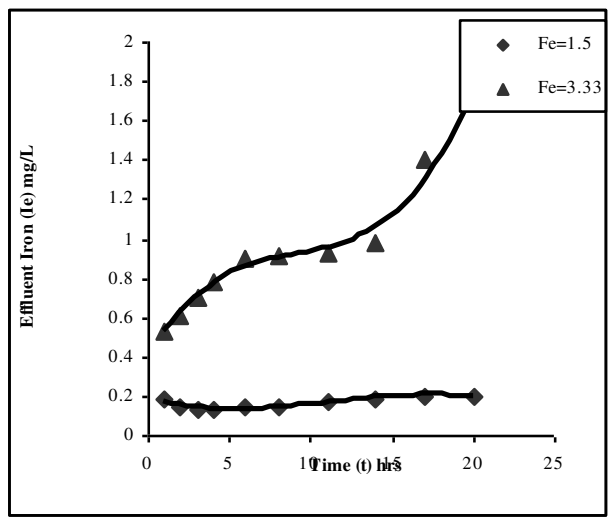

Fig. (21b) The effluent iron conc. versus time at different sand depths

For $d_{s}=70 \mathrm{~cm}, R=60 \mathrm{~m}^{3} / \mathrm{m}^{2} /$ day

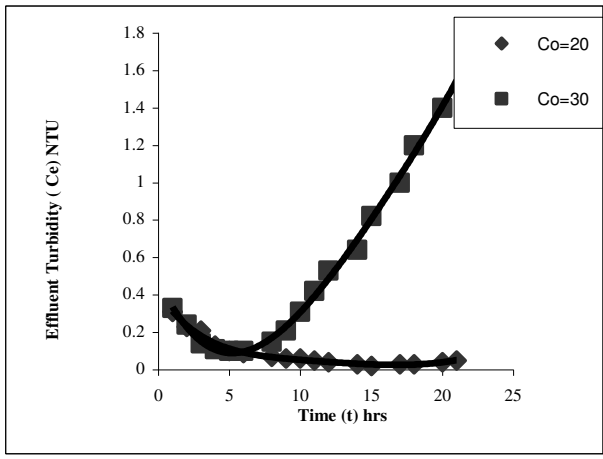

Fig. (22a) The effluent turbidity versus time at different influent turbidity.

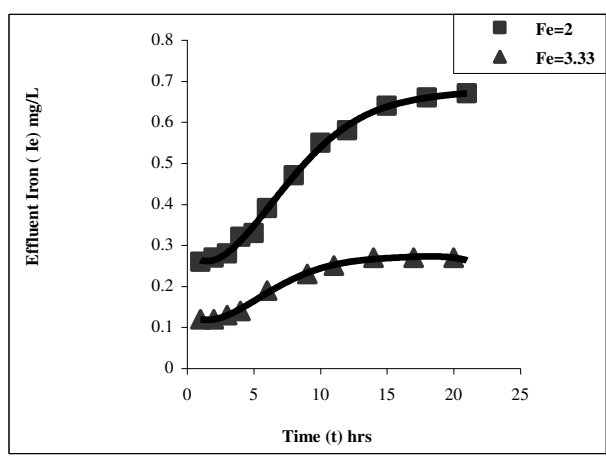

Fig. (22b) The effluent iron conc. versus time at different sand depths 
For $\mathrm{d}_{\mathrm{s}}=70 \mathrm{~cm}, \mathrm{R}=200 \mathrm{~m}^{3} / \mathrm{m}^{2} /$ day

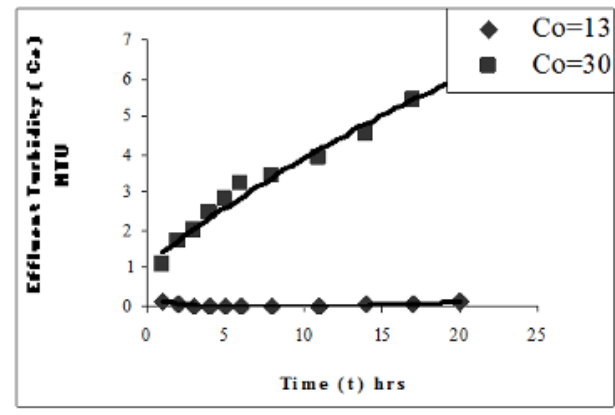

Fig. (23a) The effluent turbidity versus time at different influent turbidity.

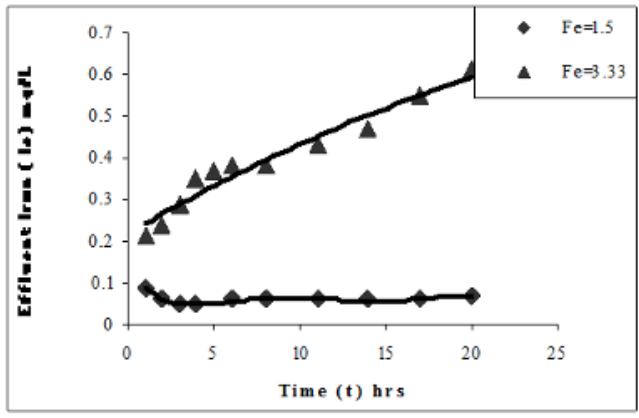

Fig. (23b) The effluent iron conc. versus time at different sand depths

The above results can be explained as on the first hours of run, the filter is normally clean and the spacing (voids) between sand particles are large enough to pass most of suspended solids. But, with the time running, the individual particles may block the pores. So, as the porosity of the filter media decreases the effluent turbidity decreases until a certain time and the effluent turbidity increases again especially for small sand depths.

\section{4- CONCLUSIONS}

This paper investigates the ability of removing iron salt from groundwater by using aeration and filtration system without any chemical additions. As a result from the previous discussions it may be concluded that:

1- The most economical sand depth according to the Egyptian Standard limit for

Drinking Water for both, effluent turbidity (1NTU) and effluent iron concentration

$(0.3 \mathrm{mg} / \mathrm{l})$ are be summarized as;

a- The economical sand depth is $40 \mathrm{~cm}$ when influent turbidity is $\leq 13 \mathrm{NTU}$ and filtration rate $\leq 200 \mathrm{~m}^{3} / \mathrm{m}^{2} /$ day.

b- The best sand depth is $\geq 70 \mathrm{~cm}$ when influent turbidity is $\leq 20$ NTU and filtration rate is $\leq 120 \mathrm{~m}^{3} / \mathrm{m}^{2}$ / day.

c- The best sand depth is more than $70 \mathrm{~cm}$ when influent turbidity is $\leq 30 \mathrm{NTU}$ and filtration rate is $\leq 200 \mathrm{~m}^{3} / \mathrm{m}^{2} /$ day.

Table (1) summarizes the obtained results for different investigated parameters.

Table (1) The economical values of sand depth with respect the range of filtration rates, the limit of influent concentration iron and the limit of influent turbidity

\begin{tabular}{|c|c|c|c||}
\hline $\begin{array}{c}\text { Influent } \\
\text { concentration iron } \\
(\mathbf{~ m g / l})\end{array}$ & $\begin{array}{c}\text { Influent turbidity } \\
\text { NTU }\end{array}$ & $\begin{array}{c}\text { Range of filtration } \\
\text { rates } \mathbf{~ m}^{\mathbf{3}} / \mathbf{m}^{\mathbf{2}} / \mathbf{d a y}\end{array}$ & $\begin{array}{c}\text { Economical sand } \\
\text { depth cm }\end{array}$ \\
\hline \hline$\leq 1.5$ & $\leq 13$ & $\leq 200$ & $\geq 40$ \\
\hline \hline$\leq 2$ & $\leq 20$ & $60-120$ & $\geq 70$ \\
\hline \hline$\leq 3.33$ & $\leq 30$ & $60-200$ & $>70$ \\
\hline
\end{tabular}


2- After aeration of raw water most of the turbidity is settled during the first time of filtration.

3- Increasing in the filtration rate with constant sand depth increases the influent turbidity.

\section{5- REFERENCES}

1- SAAD, A.G., "Iron \& Manganese Removal in Water Treatment", M. Sc. Thesis, Faculty of Engineering, Ain Shams University, Cairo, June, (1996).

2- AWWA, "Basic Science Concepts and Applications", AWWA, Denver, CO., (1984).

3- AWWA, "Introduction to Water Treatment ", Vol. 2, AWWA, Denver, (1984).

4- DROSTE, R.L., "Theory and Practice of Water and Wastewater Treatment ", John Wiley and Sons, Inc., N.Y., (1997).

5- HAMMER, M.J., and HAMMER, M.J., "Water and Wastewater Technology ", $6^{\text {th }}$ ed., Pearson Prentice Hall, N.J., ( 2008).

6- IBRAHIM, M.S., "Iron Removal from Groundwater by Oxidation and Filtration ", $2^{\text {nd }}$ Ain Shams University International Conference, April (2007).

7- McGhee, T.J., "Water Supply and Sewerage", 6 ${ }^{\text {th }}$ ed., McGraw-Hill, Inc., N.Y., (1991).

8- Ministry of Housing and Utilities, "The Egyption Code of Design and Construction of Water and Wastewater Treatment Plants", vol. 3, "Water Treatment", Cairo, 2005.

9- MONTGOMERY, I.M., Consulting Engineers, Inc., "Water Treatment Principles and Design ", John Wiley \& Sons, Ltd., N.Y., (1985).

10- RUZAEK, E.H., "A Pilot Plant Study for Iron and Manganese Removal from Groundwater by Natural Aeration, Chlorination, Sedimentation and Filtration", M. Sc. Thesis, Faculty of Engineering, Cairo University, Cairo, Nov., (1999).

\section{تنقية المياه الجوفية المهواه باستخدام المرشحات الرملية السريعة}

تعتبر المياه الجوفية في مناطق الريف المصري وكذلك المناطق الصحراوية مصدرا رئيسيا لمياه الثرب لسكان تلك المناطق .وحيث أن معظم مياه الآبار غير مطابقة للمواصفات القياسية لمياه الثرب نظر لاحتوائها على الكثير من الأملاح الضارة ومنها أملاح الحديد والتي تؤثز سلبيا على جودة المياه وعدم صلاحيتها للشرب .لذا كان الاتجاه إلى إيجاد الحلول المناسبة للتغلب على تللك المشكلة بأقل التكاليف الممكنة .

وتعتبر التهوية من أرخص وأفضل الوسائل المستخدمة لإزالة أملاح الحديد الذائبة في مياه الآبار وتحويلها إلى صورة غير ذائبة يمكن إزالتها باستخدام المرشحات المناسبة .وعليه فقد أجريت هذه الدراسة لتجربة واختبار مدى نجاح أعمال التهوية البسيطة المتبوعة بالترشيح بدون أية إضافات كيماوية لإزالة 
أملاح الحديد الذائبة بعد تهويتها وذلك في وجود بعض المتغيرات التي تؤثز على جودة المياه المنقاة

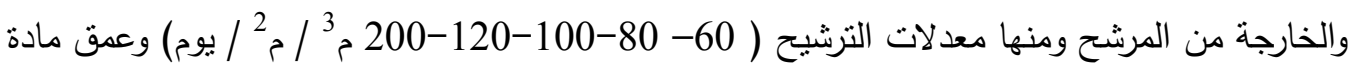

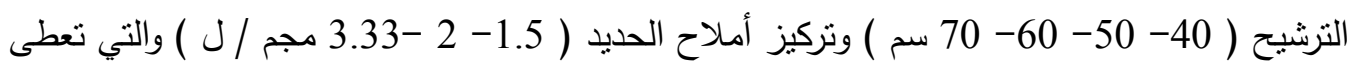
قيما للعكارة بعد تهويتها لفترة 30 دقيقة قبل الترشيح مقدارها (13، 20، 30 وحدة عكارة أندارة) على التوالى.

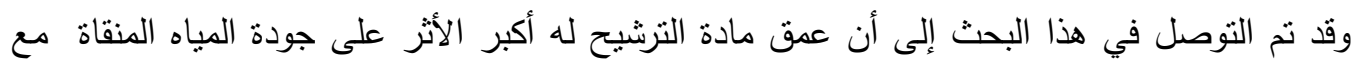

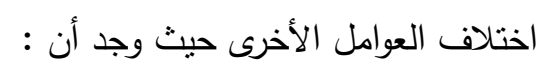

1- عمق رمل الترشيح = 40 سم فأكثر هو الأفضل فى حالة التركيزات الصغيرة لأملاح الحديد

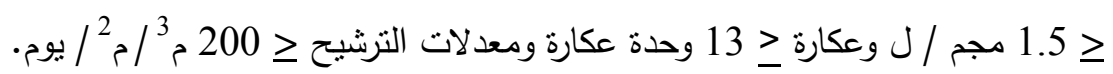

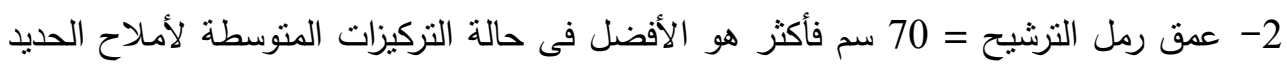

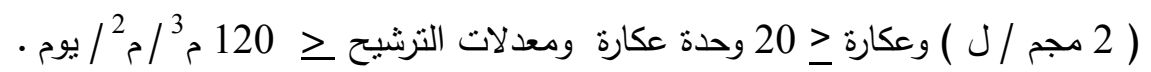

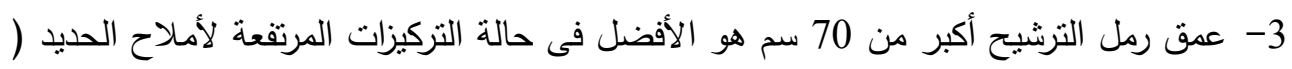

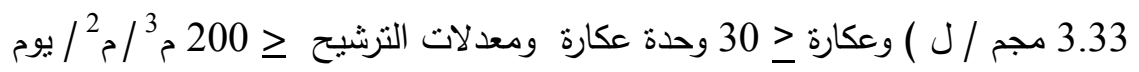
كما لوحظ أن الفاقد الهيدروليكي في المرشح تراوح بين 7.33 - 45 سم فى جميع التجارب وأن درجة الأس

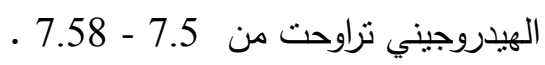

